\title{
LEDAKAN AMONIUM NITRAT: FAKTOR PEMICU URGENSI PERUBAHAN SISTEM POLITIK DI LEBANON
}

\author{
Harmiyati ${ }^{1}$ \\ ${ }^{1}$ Jurusan Ilmu Hubungan Internasional FISIP UPN “Veteran” Yogyakarta \\ *Email Penulis korespondensi: harmiyati@upnyk.ac.id
}

\begin{abstract}
Abstrak
Lebanon adalah suatu negara dengan system politik konfesional, yang membagi-bagi kekuasaan politik berdasarkan komposisi keagamaan. Sistem politik ini rapuh dan menjadi kendala dalam pembentukan integrasi nasional. Kerapuhan system politik ini sering menjadi sumber ketidakstabilan politik dan ekonomi, sekalipun demikian system ini tetap dipertahankan sampai sekarang. Masalah-masalah ini diperburuk lagi dengan fakta bahwa masyarakat Lebanon secara eksklusif terkonsentrasi di wilayah-wilayah tertentu yang menjadi pemicu terjadinya kesenjangan social dan ekonomi. Di lain pihak, tingkat korupsi yang semakin meningkat diantara para elit politik yang berkuasa telah engakibatkan kekacauan social, politik, dan ekonomi tidak dapat dihindarkan.
\end{abstract}

Kata kunci: Lebanon, Sistem Konfesional, Eksklusivisme, Ketidakstabilan Politik, Krisis Ekonomi

\begin{abstract}
Lebanon, a country with a confessional political system, fragmented its political power based on the composition of religions. The political system is fragile and become an obstacle in creating national integrity. The fragility of the political system has always been the source of unstable politics and economics, however, the system remains until now. These problems are worsened by the fact that Lebanese community are exclusive in certain areas based on their religion, thus it triggers the imbalance of social and economic. On the other hand, the number of corruptions in the country has increased among the political elites hence social, political, and economical chaos are undeniable.
\end{abstract}

Keyword: Lebanon, Confessional System, Exclusivism, Political Unstability, Economic Crises. 


\section{Paradigma: Jurnal Masalah Sosial, Politik, dan Kebijakan \\ http://jurnal.upnyk.ac.id/index.php/paradigma/index P-ISSN: 1410-3133. E-ISSN: xxxx-xxxx}

\section{Pendahuluan}

Pada tanggal 4 Agustus 2020 yang lalu, sebuah ledakan dahsyat terjadi di Pelabuhan Beirut, Lebanon, yang telah menewaskan sebanyak 200 orang, melukai 6.000 orang, dan 300.000 orang kehilangan tempat tinggal. Ledakan yang dipicu oleh terbakarnya sebuah gudang ammonium nitrat milik perusahaan pembuat bahan peledak tambang di Mozambik, Fabrica de Explosivos Mocambique (FEM), telah memicu demonstrasi besar-besaran di seluruh Lebanon. Aksi-aksi demonstrasi rakyat turun ke jalan bahkan telah berlangsung jauh sebelum terjadinya ledakan ammonium nitrat, yaitu masa sebelum terjadinya pandemi covid-19. Mereka menuntut perubahan sistem politik dan mundurnya para elit politik karena ketidakmampuan mengurus negara. Persoalan ini menimbulkan pertanyaan : mengapa sistem politik Lebanon harus diubah ?

\section{Kajian Pustaka}

Untuk menjawab pertanyaan mengapa masyarakat atau sekelompok orang melakukan protes massa atau demonstarsi secara besar-besaran, peneliti berusaha menjelaskan dengan menggunakan Teori Deprivasi Relatif oleh Ted Robert Gurr (2010). Teori ini sebenarnya cenderung bersifat psikologis dan sosiologis, akan tetapi tepat digunakan untuk mengamati suatu kondisi social politik suatu masyarakat yang mengalami ketidakadilan atau ketidakpuasan. Teori ini menjelaskan suatu keadaan psikologis dimana seseorang merasakan ketidakpuasan atau kesenjangan atau kekurangan yang subyektif pada saat keadaan diri dan kelompoknya berbeda dengan kelompok lain. Deprivasi bisa menimbulkan persepsi ketidakadilan yang muncul karena deprivasi akan mendorong ketidakpuasan.

Menurut Ted Robert Gurr, factor penyebab yang paling mendasar dari terjadinya tindakan kekerasan massa atau revolusi adalah timbulnya ketidakpuasan sebagai akibat adanya penghayatan atau persepsi mengenai sesuatu yang hilang yang disebut deprivasi relative. Gurr mendefinisikan deprivasi relative adalah suatu kesenjangan yang dipersepsikan antar nilai harapan (value expectations) dan nilai kemampuan (value capabilities). Nilai (value) adalah peristiwa atau kejadian, obyek dan kondisi yang diperjuangkan orang. Contoh dalam kasus ini adalah munculnya ketidakpuasan massa rakyat Lebanon akibat menurunnya tingkat kesejahteraan dan munculnya kesenjangan social-ekonomi antara mayoritas rakyat dengan segelintir elit politik yang berkuasa sangat lama dan bersifat oligarkis sebagai akibat dilanggengkannya penerapan system politik confessional. Massa rakyat yang kecewa dengan kondisi ketidakadilan social-politik, dan dengan dipicu oleh krisis ekonomi yang berkepanjangan serta peristiwa ledakan ammonium nitrat ini kemudian memaksa mereka turun ke jalan.

Gurr menyatakan bahwa deprivasi relative adalah sinonim dengan frustrasi. Menurutnya ada tiga jenis deprivasi, yaitu:

1. Decremental deprivation, yaitu suatu kondisi kehilangan tentang apa yang dipikirkan orang bahwa itu seharusnya mereka miliki. Mereka mengalami deprivasi ini dengan menunjuk pada kondisi masa lalu yang dialaminya. Beragam situasi yang mungkin dapat menyebabkan deprivasi ini, misalnya depresi atau resesi ekonomi, pemberlakuan aturan, kemunduran pada 


\section{Paradigma: Jurnal Masalah Sosial, Politik, dan Kebijakan \\ http://jurnal.upnyk.ac.id/index.php/paradigma/index P-ISSN: 1410-3133. E-ISSN: xxxx-xxxx}

sejumlah kesempatan yang ada, seperti misalnya tenaga kerja yang tidak cakap dalam suatu masyarakat yang meningkat teknologinya, sehingga banyak orang yang menderita reduksi status, kesulitan ekonomi, dan perasaan tidak aman. Dengan demikian, decremental deprivation adalah keadaan ketika value expectations dan value capabilities dalam waktu tertentu berjalan sejajar, tetapi pada suatu saat tertentu value capabilities menurun, sehingga terdapat jarak antara kedua value itu yang semakin lama semakin membesar.

2. Aspirational deprivation, yaitu suatu kondisi dimana jarak antara value expectations dengan value capabilities tidak lagi sejajar, karena meningkatnya value expectations sedang value capabilities tetap. Dalam situasi ini orang tidak merasa kehilangan, tetapi mereka marah karena tidak sarana untuk memperoleh harapan yang baru, misalnya meningkatnya harapan akan beberapa komoditas dalam persediaan yang terbatas, harapan mengenai beberapa nilai baru yang sebelumnya tidak pernah mereka miliki, seperti partisipasi dalam dunia kerja atau kesamaan kelas social, dll.

3. Progressive deprivation, yaitu suatu kondisi terdeprivasi yang dimulai dengan kenaikan kedua values secara bersama-sama, tetapi pada suatu saat value expectations terus meningkat sedang value capabilities justru menurun sehingga terjadi jarak antara kedua values yang makin lama semakin membesar. Perkembangan ini pada umumnya terjadi pada masyarakat yang mengalami sejumlah perubahan, misalnya seorang karyawan yang dipecat dari suatu perusahaan tempatnya bekerja karena perusahaan menuntut kemampuan sumber daya manusia yang menguasai teknologi canggih. Perubahan yang tidak sejajar dengan meningkatnya harapan ini mengakibatkan munculnya ketidakpuasan.

Dari ketiga jenis deprivasi di atas, protes massa di Lebanon dapat diidentifikasi sebagai jenis decremental deprivation, kondisi resesi ekonomi yang berkepanjangan mengakibatkan rakyat mengalami kesulitan ekonomi, sementara kesenjangan social semakin melebar akibat pelanggengan system politik oligarkis.

\section{Hasil dan Pembahasan}

Sistem Konfesionalisme Lebanon

Sistem politik “confessional' atau "consociational” yang berlaku di Lebanon sebenarnya merupakan peninggalan sistem "millet" di jaman Kekaisaran Ottoman, Turki, yang membagi-bagi kekuasaan pemerintahan berdasarkan komposisi keagamaan.(M.A.Rais, 1989:111). Sistem ini sesungguhnya sangat rapuh, dan menjadi salah satu kendala dalam mewujudkan identitas nasional, yang berujung pada kesulitan mewujudkan legitimasi politik di Lebanon, akan tetapi sistem ini terus diadopsi oleh Pemerintah Lebanon dan menjadi dasar dalam pelaksanaan pemerintahan hingga saat ini. Sistem politik yang dikukuhkan dalam Pakta Nasional (Al Mitzaq Al Wathani) 1943 dan disponsori oleh Perancis ini menetapkan bahwa penduduk Muslim akan bergabung dengan penduduk Kristen dalam membela kedaulatan Lebanon, dengan syarat penduduk Kristen tidak akan mencari proteksi Barat bagi Lebanon dan tidak akan menyetujui intervensi Barat dalam masalah Lebanon; penduduk Kristen akan membagi kekuasaan dengan penduduk Muslim berdasarkan rasio 6:5 bagi posisi-posisi pemerintahan baik di lembaga legislatife maupun eksekutif. 


\section{Paradigma: Jurnal Masalah Sosial, Politik, dan Kebijakan}

http://jurnal.upnyk.ac.id/index.php/paradigma/index P-ISSN: 1410-3133. E-ISSN: Xxxx-xxxx

Pakta Nasional 1943 juga mengatur bahwa presiden harus berasal dari kelompok Kristen Maronit, perdana menteri dari golongan Islam Sunni, dan ketua parlemen dari golongan Islam Syi'ah.(Sihbudi, 1991:29). Pakta Nasional ini merupakan sebuah perjanjian tidak tertulis (konvensi) yang dibuat berdasarkan sensus penduduk tahun 1932. Akan tetapi, dengan berjalannya waktu, komposisi demografis masyarakat Lebanon menjadi berubah. Pada tahun 1970 jumlah penduduk Muslim Syi'ah semakin besar dan menjadi mayoritas, sehingga mereka menuntut perubahan sistem konfesional agar mencerminkan kondisi yang lebih obyektif dan adil. Usulan ini ditolak oleh mereka yang telah menikmati kondisi statusquo selama berpuluh-piluh tahun, terutama oleh kelompok Kristen Maronit, yang memegang kekuasaan untuk memperkaya kelompoknya sendiri. Sementara kelompok Muslim, baik Sunni maupun Syi'ah telah mengalami keterbelakangan ekonomi dan pendidikan akibat pembagian kekuasaan berdasarkan sistem tersebut. Kesenjangan ekonomi dan ketidakadilan dalam pembagian kekuasaan ini kemudian memicu perang saudara pada tahun1958, berkat intervensi Amerika Serikat pada waktu itu konflik berhasil diakhiri. Namun, perang saudara kembali terjadi dan memakan waktu yang panjang (tahun 1975-1990) sebagai akibat semakin kompleksnya persoalan.

Pasca perang saudara, Pakta Nasional 1943 kemudian direvisi berdasarkan Perjanjian Ta'if tahun 1989, yang membagi kekuasaan dengan rasio 1:1 untuk kelompok Kristen dan Islam. Meskipun demikian, Perjanjian Ta'if tetap meneguhkan sektarianisme sebagai elemen penting dalam politik Lebanon, sehingga tidak menutup kemungkinan sistem ini akan memicu munculnya konflik-konflik berikutnya di kemudian hari. Tabel di bawah menjelaskan alokasi kursi parlemen Lebanon sebelum dan sesudah Perjanjian Ta'if.

Tabel 1. Alokasi Kursi Parlemen Lebanon

\begin{tabular}{|c|c|c|c|}
\hline No & Agama & Sebelum Perjanjian Ta'if & Sesudah Perjanjian Ta'if \\
\hline 1. & Kristen Maronit & 30 & 34 \\
\hline 2. & Ortodoks Timur & 11 & 14 \\
\hline 3. & Katolik Melkit & 6 & 5 \\
\hline 4. & Ortodoks Armenia & 4 & 1 \\
\hline 5. & Katolik Armenia & 1 & 1 \\
\hline 6. & Protestan & 1 & 1 \\
\hline 7. & Kristen minoritas lainnya & 1 & 64 \\
\hline & Total Kristen & 54 & 27 \\
\hline 8. & Sunni & 20 & 27 \\
\hline 9. & Syi'ah & 19 & 2 \\
\hline 10. & Alawi & 0 & 64 \\
\hline 11. & Druze & 6 & 128 \\
\hline & Total Islam & 45 & \\
\hline & Total & 99 & \\
\hline
\end{tabular}

Sumber: Issam Michael Saliba (Okt.2007), ”Lebanon: Presidential Election and Conflicting Constitutional Interpretations", US Library Congress. 


\section{Paradigma: Jurnal Masalah Sosial, Politik, dan Kebijakan}

http://jurnal.upnyk.ac.id/index.php/paradigma/index P-ISSN: 1410-3133. E-ISSN: Xxxx-xxxx

Dari tabel di atas terlihat bahwa komposisi kursi di parlemen telah berubah pasca-Perjanjian Ta'if, kelompok muslim menjadi berimbang di parlemen. Meskipun demikian, jabatan-jabatan penting di pemerintahan tetap tidak berubah, presiden dari kelompok Kristen Maronit, perdana menteri dari kelompok Islam Sunni, dan ketua parlemen dari kelompok Islam Syi'ah. Meskipun kekuasaan presiden telah berkurang pasca-Perjanjian Ta'if, presiden tetap memiliki kewenangan yang kuat secara konstitusi, misalnya: menetapkan Undang-Undang yang disahkan oleh parlemen, mengeluarkan peraturan tambahan dalam pelaksanaan UU, dan meratifikasi perjanjian dengan negara lain. Dalam hal ini, presiden dipilh oleh parlemen untuk masa jabatan 6 tahun dan tidak dapat dipilih kembali sampai 6 tahun sejak masa jabatan pertama berakhir. Sementara perdana menteri dan wakilnya ditunjuk oleh presiden setelah berkonsultasi dengan parlemen. Pemilu parlemen diselenggarakan pertama kalinya pada 29 Mei sampai dengan 19 Juni 2005, pasca penarikan pasukan Suriah dari Lebanon.

Dalam kehidupan kepartaian, pasca terbunuhnya P.M.Rafiq Al Hariri pada tahun 2005, masyarakat Lebanon terbelah ke dalam dua kubu partai politik, yaitu Aliansi 8 Maret dan Aliansi 14 Maret. Terbunuhnya P.M.Hariri ini telah memicu munculnya Revolusi Cedar, yaitu aksi demonstrasi besar-besaran masyarakat Lebanon yang menuntut ditariknya sebanyak 14.000 pasukan Suriah dari Lebanon dan mundurnya pemerintahan yang didukung oleh Suriah. Polarisasi kubu-kubu partai politik Lebanon ini dapat dijelaskan melalui tabel berikut:

Tabel 2. Koalisi Oposisi (Aliansi 8 Maret)

\begin{tabular}{|c|l|l|}
\hline No. & \multicolumn{1}{|c|}{ Nama Partai Politik } & \multicolumn{1}{|c|}{$\begin{array}{c}\text { Asal Partai Politik } \\
\text { (Unit Konstituen) }\end{array}$} \\
\hline 1. & Free Patriotic Movement & Kristen Maronit \\
\hline 2. & Amal Movement & Syi'ah \\
\hline 3. & Lebanese Democratic Party & Druze \\
\hline 4. & El Marada Movement & Kristen \\
\hline 5. & Glory Movement & Sunni \\
\hline 6. & Armenian Revolutionary Federation & Armenia \\
\hline 7. & Syrian Social Nationalis Party & Sekuler \\
\hline 8. & Arab Socialist Ba'ath Party-Lebanon Region & Sekuler \\
\hline 9. & Solidarity Party & Kristen Maronit \\
\hline 10. & Skaff Bloc & Kristen Katolik Yunani \\
\hline 11. & Popular Nasserist Organization & Sunni \\
\hline 12. & Arab Democratic Party & Alawi \\
\hline
\end{tabular}

Sumber: https://www.cnnindonesia.com/internasional/20141029160804-120-8752/afiliasi-partaidan-militan-di libanon, diakses 20-8-2020. 


\section{Paradigma: Jurnal Masalah Sosial, Politik, dan Kebijakan}

http://jurnal.upnyk.ac.id/index.php/paradigma/index P-ISSN: 1410-3133. E-ISSN: Xxxx-xxxx

Dari tabel 2 di atas dapat dijelaskan bahwa sebagian besar partai yang bergabung di Aliansi 8 Maret berideologi Syi' ah dan didukung oleh partai politik di Suriah yang dipimpin oleh anggota kelompok Hizbullah dan Amal. Aliansi ini menolak orientasi pro-Barat yang dilakukan oleh aliansi 14 Maret. Aliansi 8 Maret ini juga menguasai pemerintahan Lebanon yang dipimpin oleh P.M. Najib Mikati tahun 2011-2013. Pada tahun 2009, aliansi ini mendapat jatah kursi 120 di Parlemen.

Tabel 3. Koalisi Revolusi Cedar (Aliansi 14 Maret)

\begin{tabular}{|c|l|l|}
\hline No. & Nama Partai Politik & $\begin{array}{l}\text { Asal Partai Politik } \\
\text { (Unit Konstituen })\end{array}$ \\
\hline 1. & Future Movement & Sunni \\
\hline 2. & Lebanese Forces & Kristen Maronit \\
\hline 3. & Kataeb Party & Kristen Maronit \\
\hline 4. & Social Democrat Hunchakian Party & Armenia \\
\hline 5. & Armenian democratic Liberal Party Ramgavar & Armenia \\
\hline 6. & National Liberal Party & Kristen Maronit \\
\hline 7. & Democratic Left Movement & Sekuler \\
\hline 8. & Islamic Group & Sunni \\
\hline 9. & Democrtic Renewal & Sekuler \\
\hline 10. & Lebanese National Bloc & Kristen Maronit \\
\hline 11. & Independence Movement & Kristen Maronit \\
\hline 12. & Free Shia Movement & Syi'ah \\
\hline 13. & Syriac Union of Lebanon & Assiria \\
\hline 14. & Shuraya Party & Assiria \\
\hline 15. & Lebanese Peace Party & Sekuler \\
\hline
\end{tabular}

Sumber: https://www.cnnindonesia.com/internasional/20141029160804-120-8752/afiliasipartai-dan-militan-di libanon, diakses 20-8-2020.

Aliansi 14 Maret di atas adalah koalisi berideologi Sunni, Druze, dan Kristen yang terbentuk pada waktu Revolusi Cedar, kubu ini dipimpin oleh Saad Al Hariri, putra dari P.M. Rafiq Al Hariri yang terbunuh. Pada tahun 2009, aliansi ini mendapat jatah 90 kursi di parlemen. Perseteruan antara dua kelompok aliansi di atas yang bertujuan untuk merebut pengaruh ideologis di pemerintahan dan wilayah, semakin bereskalasi setelah meluasnya konflik Suriah ke Lebanon.

\section{Konsentrasi Eksklusif dan Ketimpangan Sosial}

Selain pemberlakuan sistem konvensional yang telah menciptakan ketidakadilan dalam masyarakat, konsentrasi demografis secara eksklusif kelompok-kelompok masyarakat sectarian Lebanon telah mengakibatkan sulitnya tercapai integrasi nasional. Secara geografis, luas wilayah Lebanon sekitar $10.400 \mathrm{~km}^{2}$, yang terdiri dari 4 wilayah, yaitu wilayah pantai, lembah Bekaa, pegunungan Lebanon, dan pegunungan Anti Lebanon (Lihat Peta). 


\section{Paradigma: Jurnal Masalah Sosial, Politik, dan Kebijakan}

http://jurnal.upnyk.ac.id/index.php/paradigma/index P-ISSN: 1410-3133. E-ISSN: Xxxx-xxxx

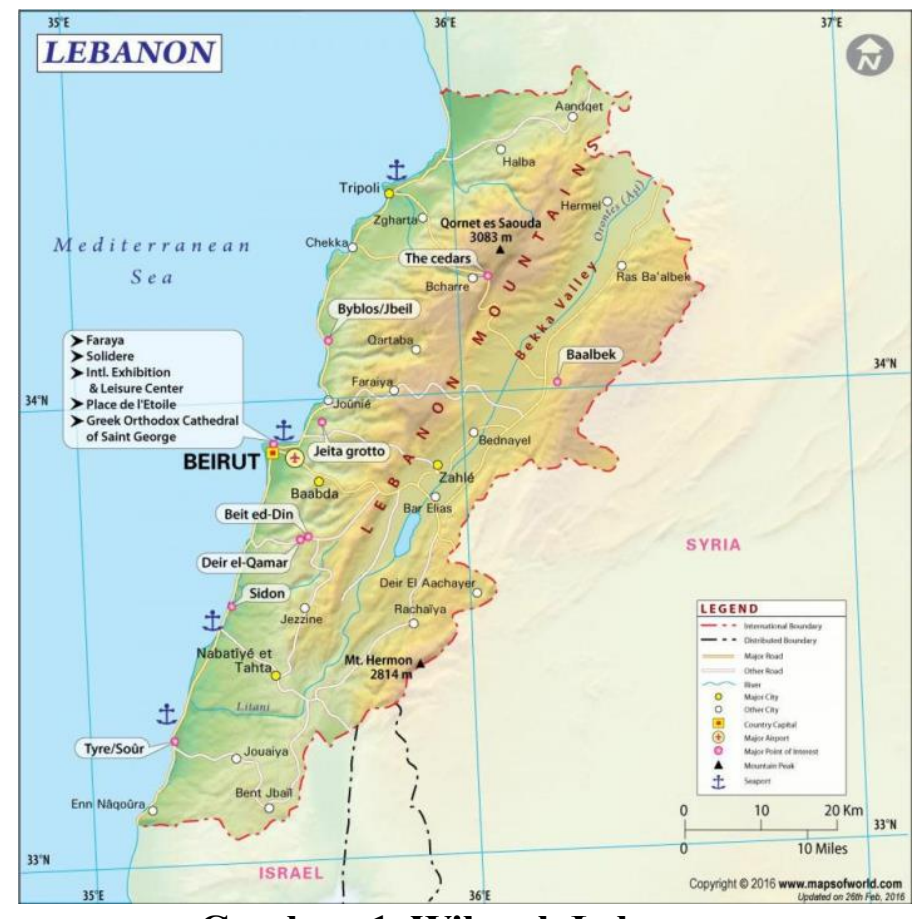

Gambar 1. Wilayah Lebanon

Di wilayah pantai yang tidak begitu luas, terdapat kota-kota penting, yaitu Beirut sebagai ibukota, Tripoli, dan Sidon. Empat kelompok masyarakat yang saat ini memainkan peran politik di Lebanon secara eksklusif terkonsentrasi di wilayah-wilayah terpisah. Golongan Maronit menempati pegunungan Lebanon bagian utara, yaitu Jubayl, Batrun, dan Baharri. Pegunungan Lebanon bagian selatan ditempati golongan Druze, kelompok Syi'ah tinggal di wilayah Lebanon Selatan yang berbatasan dengan Israel Utara dan lembah Bekka. Kristen Ortodoks berada di daerah Kura, sedang kelompok Islam Sunni menempati kota Beirut, Tripoli, dan Sidon (Zaenuddin, 1977: 25).

Kelompok Kristen Maronit menempati pegunungan Lebanon sejak abad ke 7, sebagai tempat mengungsi karena datangnya pasukan Islam. Kehadiran kelompok Kristen Maronit yang kemudian menjadi kelompok yang dominan dalam kehidupan social, politik, dan ekonomi Lebanon tidak lepas dari pengaruh Perancis sejak awal abad ke-12. Dalam peristiwa Perang Salib pada waktu itu, kelompok Maronit mendukung Perancis melawan pasukan Islam. Meskipun pada akhirnya pasukan salib kalah dalam perang di abad ke-13, hubungan yang erat antara kelompok Maronit dan Perancis telah membawa kemajuan yang berarti bagi kelompok ini. Pemerintah Perancis menjadi penghubung antara kelompok Maronit dengan gereja Roma, dan pada tahun 1580 untuk pertama kalinya didirikan Dewan Gereja di Lebanon atas bantuan Paus. Pada tahun 1584, sekolah Maronit dibuka di Roma yang bertujuan mendidik generasi muda Maronit untuk menjadi 


\section{Paradigma: Jurnal Masalah Sosial, Politik, dan Kebijakan \\ http://jurnal.upnyk.ac.id/index.php/paradigma/index P-ISSN: 1410-3133. E-ISSN: Xxxx-xxxx}

pemimpin keagamaan Lebanon. Pada tahun 1875, kaum misionaris Perancis mendirikan Universitas Saint Joseph di Beirut. Beberapa tahun sebelumnya, pada tahun 1866 orang-orang Kristen Presbyterian dari AS mendirikan American University of Beirut.

Kemajuan Maronit akibat keberpihakan Perancis di bidang pendidikan ini membawa konsekuensi semakin kuatnya kelompook ini di bidang politik dan militer. Kelompok Maronit kemudian memiliki milisi yang tangguh dan terkenal, Phalangis. Di bidang politik, kelompok ini menjadi kekuatan paling dominan dalam politik dan pemerintah Lebanon, demikian pula di bidang ekonomi yang kemudian menciptakan ketimpangan sosial. Dalam laporan resmi pemerintah, hanya 4\% penduduk Lebanon yang tergolong sangat kaya, dan mereka berasal dari golongan Kristen Maronit, 14\% penduduk termasuk kategori kaya, 32\% kategori sedang, dan 50\% hidup dalam garis kemiskinan. Mereka adalah kelompok Muslim Syi'ah, Sunni, dan Druze. Ketimpangan social, ekonomi, dan pendidikan inilah yang menjadi factor lain bagi keterpecahan Lebanon.

\section{Krisis Ekonomi}

Karut-marut persoalan sistem politik Lebanon yang hanya menghasilkan kompromi antar elit politik sektarian telah terbukti menyengsarakan rakyat. Kompromi tersebut hanya menguntungkan segelintir elit lama dan mengabaikan kepentingan rakyat banyak (yang dimaksud dengan elit lama disini, missal : mantan KSAD Jenderal Michael Aoun yang menjadi presiden, keluarga dinasti Gamayel, keluarga dinasti Chamoun, keluarga dinasti Geagea,keluarga dinasti Hariri, dst). Berkuasanya segelintir elit lama juga telah mengakibatkan praktek korupsi, kolusi, dan nepotisme yang menjadi-jadi di Lebanon. Menurut laporan Transparency International, Lebanon berada di peringkat 137 dan 180 negara pada Indeks Persepsi Korupsi 2019 (https: //www.bbc.cpm/Indonesia/dunia-5365962, diakses 20/8/20). Menurut lembaga tersebut, partaipartai politik, parlemen, dan lembaga kepolisian merupakan lembaga-lembaga terkorup di Lebanon.

Praktek korupsi yang merajalela di Lebanon kian diperparah dengan kondisi krisis ekonomi yang telah berlangsung selama satu dekade ini. Hutang Lebanon saat ini mecapai 85 juta dollar AS atau setara dengan $150 \%$ dari total pendapatan dan ini adalah yang tertinggi ketiga di dunia, angka pengangguran mencapai $25 \%$, dan hampir sepertiga dari penduduk Lebanon yang berjumlah 6 juta jiwa hidup di bawah garis kemisikinan, sementara kekayaan 7 konglomerat Lebanon mencapai 13,3 juta dollar AS. (https://news.detik.com/kolom/d-4767065/musim-semi-politik-lebanon, diakses 20/8/20). Menurut Bank Dunia, produk domestik bruto (PDB) Lebanon turun drastis menjadi USD 33 miliar tahun 2020, dari USD 55 miliar pada tahun 2018, sementara mata uang lokal (pound) terus turun setelah kehilangan $90 \%$ nilainya selama dua tahun terakhir.

Dalam kondisi yang demikian, ketidakmampuan pemerintah dalam menyediakan kebutuhan dasar telah membuat rakyat semakin marah dan frustrasi. Listrik yang seringkali padam 


\section{Paradigma: Jurnal Masalah Sosial, Politik, dan Kebijakan \\ http://jurnal.upnyk.ac.id/index.php/paradigma/index P-ISSN: 1410-3133. E-ISSN: xxxx-xxxx}

dan hanya menyala selama 4 jam sehari, kurangnya air minum yang aman, terbatasnya layanan kesehatan, dan koneksi layanan internet yang buruk memaksa rakyat turun ke jalan untuk berdemonstrasi secara besar-besaran sejak awal Oktober 2019 dan memaksa PM Saad Al Hariri meletakkan jabatan. Kondisi ekonomi yang buruk ini semakin parah sejak pandemi Covid-19 melanda Lebanon pada Februari 2020. Sejak karantina wilayah diberlakukan pada pertengahan Maret 2020 yang lalu, banyak usaha bisnis terpaksa memberhentikan staf atau mengenakan cuti tanpa gaji, sehingga nilai tukar mata uang Lebanon pada pasar resmi dan pasar gelap melebar, dan bank-bank memperketat kontrol modal. Sementara harga-harga membumbung tinggi, sehingga banyak keluarga tidak mampu membeli kebutuhan pokok. Kesulitan ekonomi ini telah memicu kerusuhan dimana-mana, lintas sektarian. Tuntutan dari para demonstran hanya satu, bubarkan sistem konfessional dan ganti dengan sistem demokrasi yang dipimpin oleh kelompok teknokrat professional, karena konfessionalisme terbukti telah menciptakan kekuasaan oligarkis yang tidak berpihak kepada rakyat.

\section{Penutup}

Lebanon, negara yang semula makmur dan terkenal sebagai "Paris of Middle East" karena pariwisatanya yang indah kini harus terpuruk menjadi negara miskin dan di ambang kehancuran. Keterpurukan Lebanon disebabkan oleh persoalan yang kompleks dan bertali-temali. Diawali dengan diterapkannya sistem politik confessional yang membagi-bagi kekuasaan berdasarkan komposisi keagamaan dari berbagai kelompok masyarakat, ditambah dengan kenyataan kesulitan mewujudkan integrasi nasional masyarakat Lebanon karena penduduknya yang tidak bisa berbaur dan terkonsentrasi secara eksklusif di wilayah-wilayah tertentu, mengakibatkan sulitnya terwujud integrasi nasional Lebanon. Pembagian kekuasaan secara sektarian tersebut telah pula memunculkan kelompok-kelompok atau keluarga-keluarga yang eksis dan dominan serta mampu mempertahankan status quo kekuasaan selama berpuluh-puluh tahun. Mereka mampu menguasai sumber-sumber ekonomi Lebanon dan memudahkannya untuk melakukan korupsi. Oligarki kekuasaan ini telah mengakibatkan munculnya ketimpangan social, politik, dan ekonomi dalam masyarakat. Kondisi mayoritas masyarakat Lebanon yang terdeprivasi secara relative dan didorong oleh munculnya krisis ekonomi bahkan sebelum terjadinya kasus pandemic covid-19, mengakibatkan munculnya ledakan social-politik yang berkepanjangan, bukan sekedar ledakan amonium nitrat sebagai factor pemicunya. Pelajaran yang dapat ditarik dari kasus Lebanon adalah pentingnya perubahan sistem politik yang terbukti rapuh dan menjadi dasar ketidakstabilan politikekonomi, ke arah sistem politik yang lebih demokratis dan egaliter. 


\section{Paradigma: Jurnal Masalah Sosial, Politik,}

dan Kebijakan

http://jurnal.upnyk.ac.id/index.php/paradigma/index P-ISSN: 1410-3133. E-ISSN: Xxxx-xxxx

\section{Daftar Pustaka}

Drysdale, Alasdair (1985). The Middle East and North Africa, A Political Geography, Oxford University Press, New York.

Hudson, Michael (1997). Arab Politics, The Search for Legitimacy, Yale University Press, USA. Gurr, Ted Robert (2010). Why Men Rebel, Princeton University Press, New Jersey.

Rais, M. Amien (1989). Timur Tengah, PAU, UGM.

Saliba, Issam Michael (2007). "Lebanon: Presidential Election and Conflicting Constitutional Interpretations", US Library Congress.

Sihbudi, Riza (1991). Bara Timur Tengah, Mizan, Bandung. (2007). Menyandera Timur Tengah, Mizan, Jakarta.

Zaenuddin, A. Rachman (1977). "Beberapa Aspek Kesejarahan perkembangan Struktur Sosial dan Politik di Lebanon”, Masalah-Masalah Internasional Masa Kini, No.8, 1977.

\section{Website}

https://www.cnnindonesia.com/internasional/20141029160804-120-8752/afiliasi-partai-danmilitan-di libanon, diakses 20-8-2020.

https://news.detik.com/kolom/d-4767065/musim-semi-politik-lebanon, diakses 20/8/20 